\title{
PERBANDINGAN NORMA HUKUM TINDAKAN PENGEMANAN PERDAGANGAN (SAFEGUARDS) ANTARA INDONESIA DAN AMERIKA SERIKAT
}

\author{
Mahfud Fahrazi* \\ Fakultas Hukum Universitas Islam Kadiri \\ Jl. Sersan Suharmaji Nomor. 38, Manisrenggo, Kota Kediri, Kediri, Jawa Timur 64128. Indonesia.
}

\begin{abstract}
This study examines the comparison of legal norms on trade safeguards measures between Indonesia and the United States. The purpose of this study is to analyze the comparison of legal norms on trade safeguards measures between Indonesia and the United States. This study uses a type of normative legal research (legal reseach) with the approach to the legislation and comparative approach. The results of this study explain that there are two components that provide a clear picture of the differences in Safeguards provisions in Indonesia and those in America, namely: (1) Form and Content of Safeguards legislation. (2). Head of State's involvement in implementing Safeguards.
\end{abstract}

Keywords: Safeguards, Comparison of Legal Norms, Indonesia and America.

\section{Intisari}

Penelitian ini mengkaji tentang perbandingan norma hukum Tindakan Pengamanan Perdagangan (Safeguards) antara Indonesia dan Amerika Serikat. Tujuan penelitian ini untuk menganalisa perbandingan norma hukum safeguards antara Indonesia dan Amerika Serikat. Penelitian ini menggunakan jenis penelitian hukum normatif (legal research) dengan pendekatan pendekatan perundang-undangan serta pendekatan komparatif. Hasil penelitian ini menejelaskan bahwa bahwa terdapat dua komponen yang memberikan gambaran jelas tentang perbedaan ketentuan safeguards yang terdapat di Indonesia dengan ketentuan yang terdapat di Amerika, yaitu: (1) Bentuk dan Isi perundang-undangan safeguards. (2). Keterlibatan Kepala Negera dalam safeguards.

Kata Kunci: Tindakan Pengaman Perdagangan (safeguards), Perbandingan Norma Hukum, Indonesia dan Amerika.

\section{Pokok Muatan}

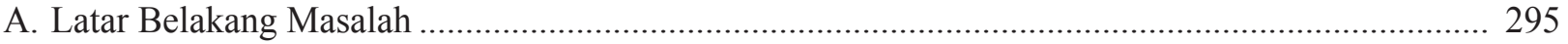

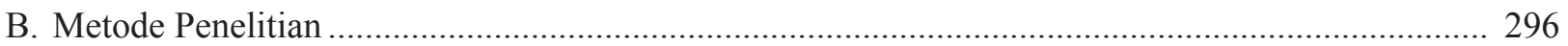

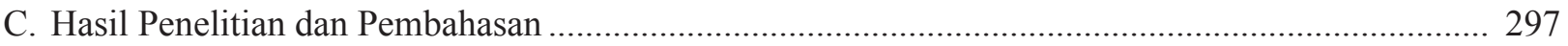

1. Norma Hukum Tindakan Pengamanan Perdagangan (Safeguards) di Indonesia dan Amerika. .. 297

2. Perbandingan Norma Hukum Tindakan Pengamanan Perdagangan (Safeguards) di Indonesia

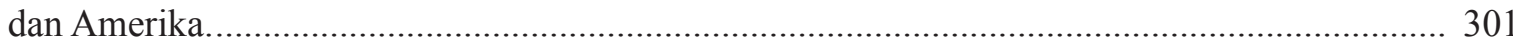

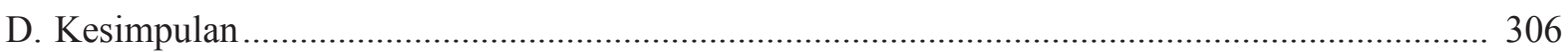

* Alamat korespondensi: mahfud@uniska-kediri.ac.id 


\section{A. Latar Belakang Masalah}

Perdagangan internasional merupakan bidang yang berkembang cepat dengan ruang lingkup yang luas. Terdapat berbagai motif atau alasan mengapa negara sebagai subjek hukum melakukan transaksi dagang internasional, diantaranya untuk meningkatkan pertumbuhan ekonomi yang merupakan kunci memasuki jalur pembangunan yang mencakup keseluruhan kegiatan masyarakat ke arah tingkat yang lebih tinggi. ${ }^{1}$ Meskipun didasari pada motivasi di atas, tetapi pada praktiknya hal tersebut tidak cukup memberikan jaminan bahwa perdagangan internasional selalu sesuai pada jalur yang diharapkan. Pada sisi lain setidaknya terdapat dampak yang timbul sebagai konsekuensi praktis dari adanya sistem perdagangan bebas, seperti timbulnya lonjakan barang impor yang dapat menimbulkan ancaman kerugian serius atau kerugian serius kepada industri domestik negaranegara anggota.

Hal tersebut tentu saja akan memberikan tekanan terhadap eksistensi dan produktivitas industri nasional untuk dapat bertahan dalam persaingan pasar, karena pada dasarnya dengan keadaan bagaimanapun industri nasional dituntut harus selalu siap untuk bersaing dengan industri asing yang sebagian besar telah memiliki kemapanan dan keunggulan dari segi kualitas produk dan harga yang ditawarkan. Menyadari terdapat konsekuensi praktis yang dapat memberikan ancaman kepada industri domestik negara anggota sehingga memungkinkan terjadinya penyimpangan dalam proses liberalisasi perdagangan, maka WTO sebagai organisasi perdagangan dunia membuat sebuah katup pengaman agar kegiatan liberalisasi perdagangan yang saling menguntungkan dapat terwujud, yaitu dengan pembentukan ketentuan safeguards. ${ }^{2}$

Setelah dibentuknya Undang-Undang Nomor 7 Tahun 1994 tentang Pengesahan Agreement Establishing The Word Trade Organization, Indonesia sebagai salah satu negara berkembang turut memperhatikan masalah-masalah yang terkait dengan safeguards sebagai upaya melindungi industri dalam negeri yang diwujudkan melalui pembentukan beberapa aturan, diantaranya seperti pembentukan Undang-Undang Nomor 7 Tahun 2014 tentang Perdagangan serta Peraturan Pemerintah Republik Indonesia Nomor 34 Tahun 2011 tentang Tindakan Anti Dumping, Tindakan Imbalan dan Tindakan Pengamanan Perdagangan.

Persoalannya, jika dicermati ketentuan Undang-Undang Nomor 7 Tahun 2014 tentang Perdagangan, maka sangat terlihat bahwa ketentuan di dalamnya hanya bersifat "sumir" hanya menyebutkan sedikit dan terbatas pada legalisasi atau pandangan umum tentang beberapa kebijakan pengamanan perdagangan. Hal tersebut sangat bertolak belakang jika dibandingkan dengan Pasal 70 Peraturan Pemerintah Republik Indonesia Nomor 34 Tahun 2011 tentang Tindakan Anti Dumping, Tindakan Imbalan dan Tindakan Pengamanan Perdagangan, yang dalam hal ini jauh lebih lengkap sebagai landasan hukum utama bagi tindakan pengamanan tersebut.

Kondisi tersebut sangat berbeda jika dibandingkan dengan kebijakan pemerintah Amerika Serikat yang dari awal sejak tahun 1951 telah resmi memasukkan perjanjian safeguards ke dalam Undang-Undang perdagangan. Diawali dari landasan pembenaran dilakukannya safeguards sampai pada pengaturan standar relatif terendah

\footnotetext{
Kartadjumena, 1986, Sistem Forum dan Lembaga Internasional, UI Press, Jakarta, hlm. 232

Argumen ekonomi tindakan pengamanan perdagangan adalah bahwa tindakan tersebut diperlukan mengingat akibat terbukanya pasar domestik sebagai konsekuensi dari konsesi-konsesi perdagangan sebagai komitmen terhadap liberalisasi seringkali membawa dampak melonjaknya impor secara tiba-tiba dan dalam jumlah yang tidak wajar. Hal ini merugikan atau berpotensi merugikan industri lokal, meskipun harus diakui bahwa tidak ada unsur-unsur kecurangan atau ketidakjujuran dalam praktek perdagangan eksportir asing. Remedi perdagangan, dalam hal ini safeguard baik berupa pengenaan bea masuk tambahan dan/atau pembatasan impor diperlukan untuk memberi kesempatan kepada industri lokal untuk "bernafas" dari masifnya kompetisi asing. Selama masa remedi, industri lokal akan memiliki kesempatan untuk melakukan penyesuaian-penyesuaian dengan kondisi persaingan baru, baik dengan cara menambah permodalan atau pembelian mesin-mesin baru, sehingga di akhir masa remedi industri lokal bisa bersaing dengan eksportir asing. Dalam Nandang Sutrisno, "Memperkuat Sistem Hukum Remedi Perdagangan, Melindungi Industri dalam Negeri”, Jurnal Hukum Ius Quia Iustum, Vol. 2 No. 14, April 2007, hlm. 23.
} 
untuk menetapkan penyebab kerugian. Hingga kini berkembang lebih lengkap pada penjelasan rinci prosedur tindakan pengamanan perdagangan, mulai dari legalitas, aturan teknis bagaimana prosedur tindakan pengamanan perdagangan tersebut dilaksanakan, peranan dan wewenang seorang kepala negara dalam menentukan kebijakan pengamanan perdagangan, teknis dan proses monitoring, modifikasi, dan pemberhentian suatu tindakan pengamanan perdagangan, dasar pertimbangan kebijakan dan lain-lain yang lengkap dituangkan dalam satu Undang-Undang.

Bahkan pada masa kepemimpinan Presiden Barrack Obama, dalam upaya merespon laporan dari United Steelworkers, pemerintah Amerika Serikat membuat keputusan menaikkan tarif impor terhadap produk ban Cina melalui amandemen Undang-Undang Perdagangan tahun 1974 Nomor 421. Amandemen tersebut merupakan semacam ketentuan pengecualian internal dalam safeguards yang khusus ditujukan bagi kehadiran produk Cina (China Specific Safeguards), di mana melalui Undang-Undang ini pemerintah berhak menaikan tarif impor pada produk Cina bila produk tersebut terbukti diimpor dalam kuantitas yang sanggup menimbulkan kerugian pasar pada produsen domestik yang memproduksi produk sejenis.

Diperlukannya studi perbandingan sistem hukum ini dimakasudkan agar dalam pengambilan kebijakan tindakan pengamanan perdagangan yang dituangkan dalam bentuk peraturan perundangan-undangan pemerintah dapat mangadopsi ide pembentukan suatu norma hukum yang komprehensif. Maksudnya adalah bahwa perlu adanya suatu peraturan perundangundangan yang secara komprehensif mengatur seluruh aturan tentang remedy perdagangan, baik itu yang berkaitan dengan Anti Dumping, Anti Subsidi ataupun Safeguards dalam satu satu perundang-undangan yang lebih tinggi, yang dalam hal ini adalah Undang-Undang sebagaimana yang telah dilakukan oleh pemerintah Amerika Serikat dalam Undang-Undang Perdagangan tahun 1974. Hal tersebut tentuanya agar regulasi remedy perdagangan di Indonesia khususnya yang mengatur tentang safeguards tidak tumpang tindih dan berdampak pada tidak jelasnya kepastian hukum bagi masyarakat internasional yang terlibat dalam perdagangan internasional.

Bukan hanya dari segi bentuk norma hukum, dari adanya studi perbandingan ini pemerintah juga dapat mengkaji dan mempertimbangkan kembali keterlibatan lebih kepala negara dalam melakukan pengawasan dan pengambil keputusan dalam pelaksanaan tindakan pengamanan perdagangan di Indonesia. Berdasarkan penjelasan di atas, maka diketahui yang menjadi batasan masalah dalam penelitian ini adalah bagaimana perbandingan norma hukum safeguard antara Indonesia dan Amerika Serikat.

\section{B. Metode Penelitian}

Jenis penelitian ini menggunakan penelitian hukum normatif (legal reseach) yang menjadikan perbandingan hukum, baik itu norma hukum safeguards di Indonesia dan Amerika sebagai dasar kajian utama untuk meneliti permasalahan yang ditawarkan. Pendekatan yang digunakan dalam mengkaji permasalahan di atas adalah pendekatan perundang-undangan, yaitu dengan menjadikan peraturan-peraturan Safeguards sebagai dasar dalam upaya menganalisis masalah yang ditawarkan. Kemudian penelitian ini juga menggunakan pendekatan komparatif dilakukan dengan membandingkan undang-undang dalam suatu negara dengan undang-undang dari satu atau lebih negara lain mengenai hal yang sama. Adapun pendekatan perbandingan dalam penelitian ini ditekankan pada perbandingan antara norma hukum safeguards yang ada di Indonesia dengan safeguards yang ada di Amerika, kajian perbandingan hukum ini menjadi kajian utama dalam penelitian ini. ${ }^{3}$ 
Bahan hukum primer dalam penelitian ini terdiri dari perjanjian internasional, UndangUndang serta peraturan perundang-undangan lainnya, seperti Article 19 General on Tariffs and Trade (GATT), Undang-Undang Nomor 7 Tahun 2014 tentang Perdagangan, Peraturan Pemerintah Republik Indonesia Nomor 34 Tahun 2011 tentang Tindakan Anti Dumping, Tindakan Imbalan dan Tindakan Pengamanan Perdagangan dan UndangUndang Perdagangan tahun 1974 Nomor 421. Bahan hukum skunder dalam penelitian ini terdiri dari buku-buku, artikel, jurnal ataupun karya ilmiah lain yang terkait dengan penelitian ini. Kemudian terakhir adalah bahan non hukum yang terdiri dari kamus bahasa, kamus hukum, Indeks kumulatif serta bahan-bahan bantu lain sebagai pendukung penelitian.

\section{Hasil Penelitian dan Pembahasan}

1. Norma Hukum Tindakan Pengamanan Perdagangan (Safeguards) di Indonesia dan Amerika.

Sebagai salah satu instrumen remedi perdagangan, safeguards didefinisikan sebagai sebuah tindakan yang diambil pemerintah untuk memulihkan kerugian serius atau mencegah ancaman kerugian serius yang diderita oleh industri dalam negeri sebagai akibat dari lonjakan jumlah barang impor baik secara absolut maupun relatif terhadap barang sejenis atau barang yang secara langsung bersaing. ${ }^{4}$ Negara-negara anggota WTO termasuk Indonesia, diberikan kebebasan untuk membuat dan mengaplikasikan baik subtansi ataupun prosedur hukum nasionalnya sendiri. Meskipun demikian hukum nasional tersebut harus konsisten dan sejalan dengan ketentuan-ketentuan yang terdapat dalam WTO. ${ }^{5}$

Instrumen remedi perdagangan ini bagi
Indonesia merupakan salah satu unsur yang penting dalam pembagunan industri nasional, bukan hanya sekedar untuk memberikan perlindungan terhadap industri domestik khususnya bagi industri yang baru tumbuh (infant industry), tetapi juga sebagai sarana untuk membangun industri nasional yang berkelanjutan dan pada akhirnya diproyeksikan untuk mampu berkompetisi dalam perdagangan internasional. Berdasakan motivasi di atas, maka pemerintah melalui Kementerian Perdagangan telah membuat langkah antisipasi untuk merespon kemungkinan lahirnya dampak negatif sebagai konsekuensi praktis dari komitemen pemerintah terlibat dalam liberalisasi perdagangan.

Adapun langkah tersebut ditunjukkan melalui pembentukan beberapa aturan Safeguards, diantaranya seperti pembentukan Undang-Undang Nomor 7 Tahun 2014 tentang Perdagangan serta Peraturan Pemerintah Republik Indonesia Nomor 34 Tahun 2011 tentang Tindakan Anti Dumping, Tindakan Imbalan dan Tindakan Pengamanan Perdagangan.

Diresmikannya Undang-Undang Nomor 7 Tahun 2014 tentang Perdagangan menandai berakhirnya penggunaan ordonansi Belanda, dimana Undang-Undang Perdagangan ini memiliki beberapa aspek baru yang sebelumnya belum dimuat dalam ordonansi. ${ }^{6}$ Adapun hal baru yang dibahas dalam Undang-Undang Nomor 7 Tahun 2014 tentang Perdagangan diantaranya adalah keberadaan ketentuan pelindungan dan pengamanan perdagangan di Indonesia, yang selama ini peraturan tersebut hanya diatur terpisah dari Undang-Undang Dagang terdahulu seperti pada Undang-Undang Nomor 17 Tahun 2006 tentang perubahan atas Undang-Undang Nomor 10 tahun 1995 tentang Kepabeanan, lalu dibahas lagi pada Peraturan Pemerintah Nomor 34 Tahun 2011

\footnotetext{
Peraturan Pemerintah Republik Indonesia Nomor 34 Tahun 2011 tentang Tindakan Anti Dumping, Tindakan Imbalan dan Tindakan Pengamanan Perdagangan (Lembaran Negara Republik Indonesia Tahun 2011 Nomor 66, Tambahan Lembaran Negara Republik Indonesia Nomor 5225).

Nandang Sutrisno, "Memperkuat Sistem Hukum Remedi Perdagangan, Melindungi Industri dalam Negeri”...Op.cit, hlm. 238 Kementerian Perdagangan Republik Indonesia, "Selamat Datang Undang-Undang Perdagangan", Indonesia Trade Insight (INTRA), Edisi Perdana 2014, hlm. 2.
} 
tentang Tindakan Antidumping, Tindakan Imbalan dan Tindakan Pengamanan Perdagangan.

Terkait dengan ketentuan tindakan pengamanan perdagangan yang termuat dalam Pasal 69 Undang-Undang Nomor 7 Tahun 2014 tentang Perdagangan yang berisi: ${ }^{7}$

(1) Dalam hal terjadinya lonjakan jumlah barang impor yang menyebabkan produsen dalam negeri dari barang sejenis atau barang yang secara langsung bersaing dengan yang diimpor menderita kerugian serius atau ancaman kerugian serius, pemerintah berkewajiban mengambil tindakan pengamanan perdagangan untuk menghilangkan atau mengurangi kerugian serius atau ancaman kerugian serius dimaksud

(2) Tindakan pengamanan perdagangan sebagaimana dimaksud pada ayat (1) berupa pengenaan bea masuk tindakan pengamanan dan/atau kuota.

(3) Bea masuk tindakan pengamanan perdagangan sebagaimana dimaksud pada ayat (2) ditetapkan oleh menteri yang menyelenggarakan urusan pemerintahan di bidang keuangan berdasarkan usulan yang telah diputuskan oleh menteri.

(4) Penetapan kuota sebagaimana dimaksud pada ayat (2) dilakukan oleh menteri.

Mencermati ketentuan diatas, maka dapat diketahui bahwa terdapat beberapa komponen yang dapat ditetapkan sebagai unsur utama penyebab timbulnya tindakan remedi tersebut dalam kontes Undang-Undang Nomor 7 Tahun 2014 tentang Perdagangan, seperti: a) Lonjakan jumlah barang impor sejenis; b) Lonjakan jumlah barang impor yang secara langsung bersaing; c) Lonjakan jumlah barang impor tersebut menyebabkan kerugian serius bagi produsen dalam negeri; d) Lonjakan jumlah barang impor tersebut menyebabkan ancaman kerugian serius bagi produsen dalam negeri.
Selanjutnya, masih dalam aturan yang sama juga dijelaskan bahwa dalam hal terjadinya lonjakan jumlah barang impor yang menyebabkan produsen dalam negeri menderita kerugian serius atau ancaman kerugian serius, pemerintah berkewajiban mengambil safeguards untuk menghilangkan atau mengurangi kerugian serius atau ancaman kerugian serius dimaksud dengan menggunakan pengenaan bea masuk tindakan pengamanan dan/atau kuota yang ditetapkan oleh menteri.

Pasal 97 Undang-Undang Nomor 7 Tahun 2014 tentang Perdagangan juga menyebutkan bahwa untuk memberikan pertimbangan kepentingan nasional terhadap rekomendasi tindakan antidumping, tindakan imbalan, dan tindakan pengamanan perdagangan adalah tugas komite perdagangan nasional. Selanjutnya ketentuan mengenai lebih lanjut mengenai tindakan pengamanan perdagangan, tindakan antidumping, tindakan imbalan diatur dengan atau berdasarkan peraturan pemerintah. ${ }^{8}$ Dengan demikian UndangUndang Nomor 7 Tahun 2014 tentang Perdagangan dibentuk untuk menjadi salah satu landasan hukum dilaksanakannya tindakan pengamanan perdagangan apabila terjadinya lonjakan impor yang menyebabkan kerugian atau ancaman kerugian serius terhadap industri dalam negeri sekaligus menjadi sarana pemerintah untuk memajukan industri dalam negeri.

Kemudian terkait dengan Peraturan Pemerintah Nomor 34 Tahun 2011 tentang Tindakan Antidumping, Tindakan imbalan dan Tindakan Pengamanan Perdagangan. Dalam Pasal 70 dijelaskan bahwa dibentuknya ketentuan ini merupakan bagian dari upaya pemerintah untuk mengatur mengenai ketentuan dan prosedur tindakan pengamanan kepada seluruh industri dalam negeri yang mengalami kerugian serius dan atau ancaman kerugian serius akibat lonjakan impor baik secara relatif atau absolut yang masuk

Undang-Undang Nomor 7 Tahun 2014 tentang Perdagangan (Lembaran Negara Republik Indonesia Tahun 2014 Nomor 45, Tambahan Lembaran Negara Republik Indonesia Nomor 5512).

8 Undang-Undang Nomor 7 Tahun 2014 tentang Perdagangan (Lembaran Negara Republik Indonesia Tahun 2014 Nomor 45 , Tambahan Lembaran Negara Republik Indonesia Nomor 5512). 
ke wilayah Indonesia. ${ }^{9}$

Adapun aspek-aspek yang dibahas dalam ketentuan tersebut secara umum menjelaskan terkait hal-hal prosedural yang mencakup penyelidikan, tindakan pengamanan sementara, pembuktian hingga pada tindakan pengamanan tetap. Di Amerika, sebagai salah satu negara besar yang terlibat dalam liberalisasi perdagangan, pemerintah Amerika Serikat sangat memperhatikan masalahmasalah yang berkaitan dengan safeguards sebagai bagian dari upaya perlindungan industri nasional mereka dari berbagai potensi ancaman kerugian dan kerugian serius yang lahir dari adanya kompetisi impor. Pada perkembangannya ${ }^{10}$ Undang-Undang Perdagangan tahun 1974 telah menjadi dasar hukum utama untuk safeguards di Amerika Serikat hingga saat ini, dan secara spesipik pembahasan tersebut tercantum dalam Pasal 201, 202, 203 dan 204 Undang-Undang Perdagangan Amerika Serikat Tahun 1974 tentang Penetapan Persyaratan dan Tujuan dari Safeguards.

Keberadaan ketentuan tersebut tentunya tidak dapat lepas dari kepentingan dan tujuan yang secara tidak langsung akan memberikan pengaruh kepada industri domestik dan tenaga kerja yang ada di Amerika Serikat. Bagi industri domestik, dengan adanya regulasi yang mengatur tentang Safeguards tentunya diharapkan agar industri domestik di Amerika Serikat dapat berhasil bersaing dengan barang-barang impor setelah tindakan-tindakan dilakukan serta dapat mengalami sebuah transfer sumber daya secara teratur untuk kegiatan produktif yang lain.

Kemudian dalam aspek ketenaga kerjaan, dengan adanya regulasi tersebut tentunya diharapkan para pekerja yang dilepaskan dalam industri mengalami transisi kegiatan produktif secara teratur. ${ }^{11}$ Dalam Pasal 201 Undang-undang Perdagangan Amerika Serikat 1974, disebutkan bahwa: ${ }^{12}$

"Jika Komisi Perdagangan Internasional Amerika Serikat (selanjutnya dalam bab ini disebut sebagai "Komisi") pada bab 202 (b) menetapkan bahwa suatu barang yang diimpor menuju Amerika Serikat yang menyebabkan meningkatnya jumlah barang menjadi sebuah bahaya atau ancaman yang serius bagi industri domestik yang memproduksi barang serupa baik secara langsung atau tidak langsung bersaing dengan barang yang diimpor. Berdasarkan bab ini, seorang Presiden dapat mengambil langkahlangkah yang tepat dan memungkinkan untuk dilakukan melalui kekuasaannya yang mana keputusan-keputusan Presiden akan mempermudah langkah-langkah industri domestik dalam melakukan penyesuaian persaingan terhadap barang impor dan menyediakan keuntungan-keuntungan ekonomi dan sosial yang lebih besar dari pada biaya yang dikeluarkan".

Berdasarkan ketentuan di atas, dijelaskan, dimana pada kasus ditemukan peningkatan impor yang menjadi penyebab substansial timbulnya kerugian serius. Pasal 201 Undang-undang Perdagangan Amerika Serikat Tahun 1974 dapat memberikan waktu pada pemerintah Amerika Serikat untuk melakukan penyesuaian serta memungkinkan pada pembentukkan komitmen yang kuat untuk membuka pasar dalam negosiasi perdagangan. Dengan membantu membujuk industri domestik mereka untuk menerima pemotongan yang signifikan dalam tarif. ${ }^{13}$

Terkait dengan kewenangan kepala negara, Presiden memiliki kuasa untuk melaksanakan tindakan pengamanan. Ketika USITC menentukan bahwa peningkatan jumlah impor tersebut menjadi

\footnotetext{
Peraturan Pemerintah Nomor 34 Tahun 2011 tentang Tindakan Antidumping, Tindakan Imbalan dan Tindakan Pengamanan Perdagangan (Lembaran Negara Republik Indonesia Tahun 2011 Nomor 66, Tambahan Lembaran Negara Republik Indonesia Nomor 5225).

10 Undang-Undang Perdagangan Amerika Serikat tahun 1974 tentang Tindakan yang Mempermudah Penyesuaian Industri Terhadap Persaingan Impor. 
penyebab substansial adanya cedera serius atau ancaman daripadanya untuk industri dalam negeri yang memproduksi barang sejenis atau barang yang secara langsung bersaing dalam kompetisi impor. Dalam menentukan apakah peningkatan impor menyebabkan ancaman atau cedera pada industri dalam negeri, Undang-undang perdagangan AS menginstruksikan USITC untuk mempertimbangkan semua faktor yang relevan. Adapun faktor-faktor tersebut seperti peningkatan impor (baik absolut atau relatif terhadap produksi dalam negeri), cedera pada industri dalam negeri, "perlambatan signifikan" dalam produktivitas industri domestik, ketidakmampuan untuk menghasilkan "tingkat keuntungan yang wajar," terjadinya peningkatan pengangguran yang signifikan, penurunan penjualan, pangsa pasar, keuntungan, tenaga kerja, produktivitas, dan akses terhadap modal.

Berdasarkan hal ini, Pasal 201 Undangundang Perdagangan Amerika Serikat Tahun 1974 mensyaratkan bahwa Presiden hanya melaksanakan perlindungan jika ia percaya mereka akan memfasilitasi upaya tindakan perlindungan industri domestik tersebut, membuat penyesuaian positif untuk mengimpor persaingan, dan memberikan manfaat ekonomi dan sosial yang lebih besar daripada biaya. ${ }^{14}$ Berbeda dengan Pasal 201, dalam Pasal 202 Undang-Undang Perdagangan Amerika Serikat Tahun 1974 membahas secara khusus mengenai aturan teknis bagaimana prosedur safeguards tersebut dilaksanakan di Amerika Serikat. Hal tersebut diawali dari tahapan permohonan dan rencana-rencana penyesuaian, diteruskan dengan investigasi dan ketetapan komisi serta analisa terhadap faktor-faktor yang digunakan dalam menentukan kebijakan, dilanjutkan dengan upaya memberikan pertolongan sementara dan diteruskan dengan rekomendasi komisi dan laporan dari komisi hingga diakhiri pada tahapan pertimbangan permohonan bantuan yang dipercepat serta pembatasan investigasi. ${ }^{15}$

Menurut Pasal 202 Undang-undang Perdagangan Amerika Serikat Tahun 1974, sebagai perwakilan industri, Presiden, perwakilan dagang atau U.S. Trade Representative (USTR) beserta Senat Komite Keuangan bisa menyerahkan petisi kepada USITC untuk memulai investigasi. Setelah menerima permohonan, maka USITC umumnya memiliki 120 hari untuk menyelesaikan investigasi dan mengeluarkan rekomendasi kepada Presiden. USITC terdiri dari enam komisaris yang umumnya ahli dalam perdagangan internasional dinominasikan oleh Presiden dan dikonfirmasi oleh Senat Amerika Serikat. Ketika USITC merekomendasikan safeguards, biasanya rekomendasi tersebut bisa berupa tarif, kuota, atau kuota tarif dan kadang-kadang dikombinasi dengan bantuan keuangan langsung kepada industri dalam negeri. (Pembahasan ini akan dijelaskan secara rinci pada sub bahasan selanjutnya tentang USITC dan standar prosedural safeguards yang digunakan). ${ }^{16}$

Pasal 203 Undang-Undang Perdagangan Amerika Serikat Tahun 1974 secara khusus membahas mengenai sejauhmana peranan dan keterlibatan seorang kepala negara dalam upaya melindungi eksistensi industri nasional dari persaingan impor yang dapat berakibat pada lahirnya ancaman kerugian atau kerugian serius. Dalam Pasal ini dijelaskan bahwa Kepala Negara (Presiden) yang telah menerima laporan tentang keputusan mengenai adanya ancaman atau gangguan serius pada industri dalam negeri memiliki wewenang melakukan seluruh tindakan yang dinilai cocok dan memungkinkan dilakukan melalui kekuasaannya. Adapun ketetapan Presiden tersebut berupa upaya memfasilitasi Industri domestik dalam membuat langkah-langkah penyesuaian yang positif dalam

\footnotetext{
Undang-Undang Perdagangan Amerika Serikat Tahun 1974 tentang Investigasi, Kebijakan dan Saran dari Komisi. David Ryan, Op. cit., hlm. 246.

Undang-Undang Perdagangan Amerika Serikat tahun 1974 tentang Tindakan yang Diambil Presiden Setelah Penetapan Gangguan Barang Impor.
} 
bersaing dengan produk impor dan mendapatkan keuntungan ekonomi yang lebih besar serta keuntungan sosial dibandingkan dengan biaya yang dikeluarkan. ${ }^{17}$

Pasal terakhir yang khusus mengatur tentang Safeguards adalah Pasal 204 Undang-Undang Perdagangan Amerika Serikat Tahun 1974 yang menjelaskan mengenai teknis dan proses monitoring, modifikasi, dan pemberhentian suatu tindakan pengamanan perdagangan. ${ }^{18}$ Dalam Pasal ini dijelaskan bahwa Komisi memiliki keharusan memonitor perkembangan industri domestik yang terkait, meliputi kemajuan dan usaha yang spesifik yang dibuat para pekerja ataupun kelompok perusahaan di dalam industri domestik yang sedang mencoba untuk melakukan langkah-langkah penyesuaian yang positif dalam bersaing dengan barang impor. Jika pada periode awal dari tindakan yang diambil menghasilkan efek atau dampak lebih dari 3 tahun, komisi harus mengumpulkan laporan kegiatan monitoring dan menyerahkannya kepada Presiden dan Kongres.

Berdasarkan pembahasan setiap laporan, Komisi harus memberikan perhatian kepada animo masyarkat terhadap suatu barang dan memberikan alasan yang masuk akal untuk di presentasikan, untuk memperkuat bukti, dan dapat diperdengarkan. Selanjutnya atas permintaan Presiden, Komisi harus memberikan nasehat kepada Presiden atas apa yang menjadi keputusannya. Seperti kemungkinan dampak-dampak ekonomi terhadap industri khususnya industri yang sedang mengalami penurunan, memodifikasi, atau menghentikan tindakan yang masih dalam proses pertimbangan.

Terkait dengan upaya reduksi, modifikasi dan pemberhentian suatu Safeguards, sebuah tindakan yang diambil mungkin dapat dikurangi, dimodifikasi atau dihentikan oleh seorang Presiden (tetapi tidak, jika Presiden belum menerima laporan yang dibutuhkan). Dalam hal ini Presiden mempunyai wewenang untuk mengambil tindakan tambahan seperti menghilangkan tindakan yang berulang-ulang dari beberapa tindakan yang telah diambil di beberapa bagian sebelumya. Selain itu Presiden juga dibolehkan melakukan pengurangan, modifikasi tindakan yang diambil setelah menerima ketetapan Komisi.

Atas permintaan Presiden atau atas suatu permohonan dari kepentingan industri terkait yang diajukan kepada Komisi tidak kurang dari 6 bulan dan tidak lebih dari 9 bulan dari tanggal diberhentikannya tindakan yang diambil. Komisi harus melakukan investigasi untuk memutuskan tindakan selanjutnya untuk melakukan pencegahan atau perbaikan terhadap kerugian-kerugian yang serius. Kemudian apakah ada bukti bahwa industri berhasil melakukan langkah-langkah penyesuaian terhadap persaingan dengan barang impor. ${ }^{19}$

Selama pembahasan dan evaluasi diselenggarakan, Komisi memiliki keharusan berpegang pada keefektifan pendengaran masyarakat. Semua ketertarikan masyarakat pada sesuatu barang harusnya dijadikan peluang untuk mendatangkan audiensi dan merepresentasikan bukti atau sebuah testimony di beberapa responden. Selanjutnya berdasarkan laporan dari evaluasi yang telah dibuat dan para pendengar telah berpegang seharusnya telah dikumpulkan oleh komisi ke presiden dan kongres selambat-lambatnya hari ke 180 setelah hari yang mana tindakan diambil.

\section{Perbandingan Norma Hukum Tindakan Pengamanan Perdagangan (Safeguards) di Indonesia dan Amerika.}

Berdasakan pemaparan di atas, maka dapat diketahui bahwa terdapat dua komponen yang memberikan gambaran jelas tentang perbedaan ketentuan Safeguards yang terdapat di Indonesia dengan ketentuan yang terdapat di Amerika. Adapun dua komponen perbedaan tersebut, yaitu:

\footnotetext{
Undang-Undang Perdagangan Amerika Serikat tahun 1974 tentang Monitoring, Modifikasi, dan Pemberhentian Suatu Tindakan. Undang-Undang Perdagangan Amerika Serikat tahun 1974 tentang Monitoring, Modifikasi, dan Pemberhentian Suatu Tindakan. David Ryan, Op. cit., hlm. 261-263.
} 


\section{a. Bentuk dan Isi Perundang-undang- an Tindakan Pengamanan Perda- gangan (Safeguards).}

Berdasar ringkasan hasil perundingan dibidang safeguards pada putaran akhir perundingan Uruguay Round di Marrakech pada tanggal 15 April 1994 menyebutkan bahwa safeguards adalah hak darurat membatasi impor apabila terjadi peningkatan impor yang menimbulkan kerugian serius terhadap industri domestik. ${ }^{20}$ Bhagirath Lal Das mendefenisikan Safeguards sebagai pengecualian terhadap aturan umum dalam WTO yang langkah-langkah tersebut diizinkan sementara dalam situasi ketika industri dalam negeri menderita karena kenaikan impor yang tak terduga dan perlu beberapa waktu untuk menyesuaikan diri.

Menurut Bhagirath Lal Das setidaknya terdapat dua pra-kondisi yang dapat dibenarkan untuk mengambil Safeguards, yaitu: 1) Harus terdapat bukti adanya peningkatan impor. Peningkatan tersebut dapat berupa peningkatan mutlak sebenarnya atas impor atau meningkat relatif terhadap produksi dalam negeri; 2) Lonjakan impor tersebut harus menyebabkan cedera serius bagi industri dalam negeri atau mengancam untuk menyebabkan cedera serius. ${ }^{21}$

Secara subtansial kedua definisi di atas memiliki maksud bahwa Safeguards dapat menjadi salah satu solusi yang bisa menjadi bagian dari kebijakan pengamanan perdagangan. Oleh karena pentingnya peran Safeguards dalam suatu negara, maka diperlukan sebuah regulasi khusus yang dapat menjadi penyangga perbatasan untuk mencegah banyaknya tekanan yang menjurus pada perubahan struktur ekonomi dalam negeri negara-negara anggota.

Indonesia sebagai salah satu Negara berkembang turut memperhatikan masalahmasalah yang terkait dengan Safeguards sebagai upaya melindungi industri dalam negeri yang diwujudkan melalui pembentukan beberapa aturan Safeguards diantaranya seperti pembentukan UndangUndang Nomor 7 Tahun 2014 tentang Perdagangan. Persoalannya, jika dicermati ketentuan Undang-Undang Nomor 7 Tahun 2014 tentang Perdagangan, maka sangat terlihat bahwa ketentuan di dalamnya hanya bersifat "sumir" hanya menyebutkan sedikit dan terbatas pada legalisasi atau pandangan umum tentang beberapa kebijakan pengamanan perdagangan. Hal tersebut sangat bertolak belakang jika dibandingkan dengan Pasal 70 Peraturan Pemerintah Republik Indonesia Nomor 34 Tahun 2011 tentang Tindakan Anti Dumping, Tindakan Imbalan dan Tindakan Pengamanan Perdagangan, yang dalam hal ini jauh lebih lengkap sebagai landasan hukum utama bagi tindakan pengamanan tersebut.

Jika keadaan tersebut dibandingkan dengan ketentuan Safeguards di Amerika, maka terlihat perbedaan yang jelas dalam hal bentuk ketentuan. Sejak tahun 1951 pemerintah Amerika telah resmi memasukkan perjanjian tindakan pengamanan ke dalam Undang-Undang perdagangan. Diawali dari landasan pembenaran dilakukannya tindakan pengamanan perdagangan sampai pada pengaturan standar relatif terendah untuk menetapkan penyebab kerugian. ${ }^{22}$ Hingga kini berkembang lebih lengkap pada penjelasan tentang rinci prosedur tindakan pengamanan perdagangan, mulai dari

20 Muhammad Sood, 2011, Hukum Perdagangan Internasional, Rajawali Press, Jakarta, hlm. 4.

21 Bhagirath Lal Das, 1998, An Introduction To The WTO Agreements, Trade And Development Issues and The Word Organisation, Third World Netwrok, Malaysia, hlm. 29.

22 David Ryan, Op.cit., hlm. 262. 
legalitas, aturan teknis bagaimana prosedur tindakan pengamanan perdagangan tersebut dilaksanakan, peranan dan wewenang seorang kepala negara dalam menentukan kebijakan pengamanan perdagangan, teknis dan proses monitoring, modifikasi, dan pemberhentian suatu tindakan pengamanan perdagangan, dasar pertimbangan kebijakan dan lain-lain yang lengkap dituangkan dalam satu undang-undang. ${ }^{23}$

Bahkan pada masa kepemimpinan Presiden Barrack Obama, dalam upaya merespon laporan dari United Steelworkers, pemerintah Amerika Serikat membuat keputusan menaikkan tarif impor terhadap produk ban Cina melalui amandemen Undang-Undang Perdagangan Tahun 1974 Nomor 421. Amandemen tersebut merupakan semacam ketentuan pengecualian internal dalam safeguards yang khusus ditujukan bagi kehadiran produk Cina (China Specific Safeguard), di mana melalui UndangUndang ini pemerintah berhak menaikan tarif impor pada produk Cina bila produk tersebut terbukti diimpor dalam kuantitas yang sanggup menimbulkan kerugian pasar pada produsen domestik yang memproduksi produk sejenis. ${ }^{24}$

Dalam hal ini, tidak dapat dikatakan bahwa beberapa ketentuan-ketentuan safeguards yang tertuang dalam bentuk Peraturan Pemerintah tidak bagus, tapi diharapkan dengan dibentuknya dalam satu UndangUndang yang khusus mengatur tentang safeguards, baik itu mencakup tindakan dumping, tindakan imbalan dan khususnya safeguards dapat memberikan posisi yang lebih kuat sebagai landasan hukum. Karena asumsinya dengan adanya landasan hukum yang kuat tentunya akan lebih memberikan jaminan kepastian hukum pada masyarakat perdagangan internasional.

\section{b. Keterlibatan Kepala Negera dalam Tindakan Pengamanan Perdagang- an (Safeguards).}

Terkait dengan keterlibatan kepala negara dalam tindakan pengamanan perdagangan, Untuk pelaksanaan di Amerika, menurut Pasal 202 Undangundang Perdagangan Amerika Serikat Tahun 1974, sebagai perwakilan industri, Kepala Negara, perwakilan dagang atau U.S. Trade Representative (USTR) beserta Senat Komite Keuangan bisa menyerahkan petisi kepada USITC untuk memulai investigasi. Kemudian Kepala Negara dan dikonfirmasi oleh Senat Amerika Serikat juga memiliki wewenang untuk menominasikan enam komisaris USITS yang umumnya terdiri dari para ahli dalam perdagangan internasional.

Selanjutnya dalam Pasal 203 Undangundang Perdagangan Amerika Serikat Tahun 1974 secara khusus membahas mengenai sejauhmana peranan dan keterlibatan seorang kepala negara dalam upaya melindungi eksistensi industri nasional dari persaingan impor yang dapat berakibat pada lahirnya ancaman kerugian atau kerugian serius. Dalam Pasal ini dijelaskan bahwa Kepala Negara (Presiden) yang telah menerima laporan tentang keputusan mengenai adanya ancaman atau gangguan serius pada industri dalam negeri memiliki wewenang melakukan seluruh tindakan yang dinilai cocok dan memungkinkan dilakukan melalui kekuasaannya.

Adapun ketetapan tersebut berupa upaya memfasilitasi Industri domestik dalam membuat langkah-langkah penyesuaian yang positif dalam bersaing dengan produk 
impor dan mendapatkan keuntungan ekonomi yang lebih besar serta keuntungan sosial dibandingkan dengan biaya yang dikeluarkan. ${ }^{25}$ Undang-Undang ini juga menyebutkan, bahwa Kepala Negara juga berhak menolak permohonan kenaikan tarif bila kebijakan kenaikan tarif tersebut dinilai akan merugikan perekonomian negara secara keseluruhan.

Adapun contoh keterlibatan Kepala Negara tersebut seperti Amandemen Undangundang Perdagangan Tahun 1974 Nomor 421 ini pertama dikeluarkan pada Pemerintahan Presiden Bush, di mana ketika itu terdapat pengajuan sebanyak enam kasus pelanggaran Pasal 421 yang diajukan oleh industri domestik, di mana dalam enam kasus tersebut, ITC kemudian mengajukan rekomendasi adanya "kenaikan kuantitas" dan "kerugian pasar" pada Presiden Bush. Tetapi dari empat rekomendasi ITC tersebut, tidak satupun kasus yang kemudian diloloskan oleh Bush, karena dari latar belakangnya yang berasal dari partai Republik yang cenderung konsen di bidang high politics khususnya untuk program ekspansi di negara-negara Timur Tengah. ${ }^{26}$

Berdasar proses pembuatan kebijakan di Amerika Serikat, setiap elemen pemerintahan berkoordinasi satu sama lain untuk memberikan pertimbangan serta gambaran kepada Presiden sebelum menetapkan kebijakan. Pada masa pemerintahan Barrack Obama, input dalam pengambilan kebijakan Kepala Negara berasal dari berbagai masukan dari kelompok kepentingan yang dikoordinasi oleh badan pemerintah yang dalam proses pengambilan kebijakannya kemudian suara-suara tersebut masuk ke kongres dimana sebelumnya dilakukan berbagai lobby terhadap anggota kongres untuk merumuskan kebijakan sebagai pertimbangan dikeluarkannya kebijakan tersebut. Dari kelompok kepentingan masuk ke USTR dan dirapatkan bersama anggota kongres dimana NEC sebagai wakil presiden juga turut hadir dalam kegiatan tersebut. ${ }^{27}$

Setelah itu hasilnya diserahkan langsung ke Kepala Negara untuk kemudian Kepala Negara merapatkannya bersama dengan NEC dan staff ahlinya. Sehingga jika Kepala Negara merasa perlu untuk mengeluarkan kebijakan sesuai dengan aspirasi kelompok kepentingan tertentu maka keluarlah amandemen Undang-Undang Perdagangan Tahun 1974 Nomor 421 pada 11 September 2009. Kemudian ketika Presiden Obama mengumumkan kenaikan tarif impor pada produk ban Cina sebesar 35\%, di luar pajak sebesar 4\% yang sudah diterapkan sebelumnya. Tarif impor ini sendiri akan berlaku selama tiga tahun ke depan, dengan rincian $35 \%$ pada tahun pertama, $30 \%$ pada tahun kedua dan $25 \%$ pada tahun ketiga, dalam hal ini para pengusaha otomotif serta ban yang terdesak oleh impor ban dari China yang membanjiri pasar Amerika Serikat dengan harga yang sangat murah lebih merasa aman untuk mengembangkan kegiatan produksi mereka.

Antara tahun 2004-2008, kapasitas produksi ban Cina meningkat $152 \%$ dan diproyeksikan meningkat lagi sekitar 16\% pada 2010. Pada 2008, kapasitas produksi ban Cina mencapai 235,2 juta. Impor ban Amerika Serikat selama periode 2004-2008

Undang-Undang Perdagangan Amerika Serikat tahun 1974 tentang Tindakan yang Diambil Presiden Setelah Penetapan Gangguan Barang Impor.

26 Erika, 2009, Kebijakan Perdagangan Amerika Serikat : Kenaikan Tarif Impor Ban Cina Analisa Terhadap Motif Ekonomi dan Politik dari Kebijakan AS dalam Menaikkan Tarif Impor Ban Cina pada Masa Pemerintahan Obama, Thesis, Fakultas Ilmu Sosial dan Ilmu Politik Universitas Indonesia, Jakarta, hlm. 6.

$27 \quad$ Ibid., hlm. 7 
meningkat dari 14,6 juta ban menjadi 46 juta ban. Selama periode tersebut, pangsa pasar ban Cina di pasar Amerika Serikat meningkat $255 \%$, yaitu dari $4,7 \%$ menjadi $16,7 \%$. Di sisi lain, sebanyak empat pabrik ban AS ditutup pada 2006 dan 2007. Jumlah tenaga kerja yang bekerja di industri ban Amerika Serikat telah berkurang sebanyak 5.168 pekerja dibandingkan posisinya pada tahun 2004. Atas dasar pertimbangan inilah, Pemerintah Amerika Serikat mengambil kebijakan perdagangan luar negeri yang berbau proteksionisme tersebut. ${ }^{28}$

Tentunya hal tersebut berbeda dengan pelaksanaan tindakan pengamanan perdagangan yang terdapat di Indonesia. Dimana dalam hal ini Kepala Negara tidak memiliki keterlibatan apapun, karena dari awal terkait pelaksananaan safeguards sejak awal telah diserahkan kepada tiga lembaga independen, yaitu : a) Komite Pengamanan Perdagangan Indonesia (KPPI) yang memiliki kewenangan melaksanakan penyelidikan dalam rangka Tindakan Pengamanan atas Permohonan Tindakan Pengamanan terhadap produsen dalam negeri yang menderita kerugian serius dan/atau mengalami ancaman terjadinya kerugian serius, dari akibat melonjaknya impor barang sejenis atau barang yang secara langsung bersaing dengan barang produsen dalam negeri. b) Kemudian Dewan Pengamanan Perdagangan (DPP) yang memiliki kewenangan, yaitu: ${ }^{29}$

1) Penyiapan perumusan kebijakan pengamanan perdagangan di bidang monitoring dan evaluasi hambatan perdagangan, penanganan hambatan teknis perdagangan, penanganan tuduhan dumping, subsidi, safeguard.
2) Penyiapan pelaksanaan kebijakan pengamanan perdagangan di bidang monitoring dan evaluasi hambatan perdagangan, penanganan hambatan teknis perdagangan, penanganan tuduhan dumping, subsidi, tindakan pengamanan perdagangan.

3) Penyiapan penyusunan pedoman, norma, standar, prosedur, dan kriteria pengamanan perdagangan di bidang monitoring dan evaluasi hambatan perdagangan, penanganan hambatan teknis perdagangan, penanganan tuduhan dumping, subsidi, safeguard.

4) Penyiapan pemberian bimbingan teknis dan evaluasi pelaksanaan kebijakan pengamanan perdagangan di bidang monitoring dan evaluasi hambatan perdagangan, penanganan hambatan teknis perdagangan, penanganan tuduhan dumping, subsidi, Tindakan Pengamanan Perdagangan pelaksanaan urusan tata usaha dan rumah tangga Direktorat.

Selanjutnya, yang terakhir adalah c) Kementerian Perdagangan dan Kementerian Keuangan. Dalam hal penetapan bea masuk, kewenangan tersebut berada dibawah Kementerian Keuangan seperti bunyi Pasal 84 ayat (5) dan (6) Peraturan Pemerintah Republik Indonesia Nomor 34 Tahun 2011 tentang Tindakan Antidumping, Tindakan Imbalan dan Tindakan Pengamanan Perdagangan, yaitu:

"Menteri menyampaikan keputusan sebagaimana dimaksud pada ayat (4) kepada menteri yang menyelenggarakan urusan pemerintahan di bidang keuangan paling lambat 30

Erika, Kebijakan Perdagangan Amerika Serikat : Kenaikan Tarif Impor Ban Cina Analisa Terhadap Motif Ekonomi dan Politik dari Kebijakan AS dalam Menaikkan Tarif Impor Ban Cina pada Masa Pemerintahan Obama ..Op.cit., hlm. 5-9

29 Kementerian Perdagangan, "Main Tasks And Functions Of The organization" http://ditjendaglu.kemendag.go.id/index.php/home/about_us/ tupoksi, diakses tanggal 31 Januari 2020. 
(tiga puluh) hari kerja terhitung sejak tanggal rekomendasi dari KPPI." ${ }^{\prime 30}$

Berdasar hal Tindakan Pengamanan berupa pengenaan Bea Masuk Tindakan Pengamanan, menteri yang menyelenggarakan urusan pemerintahan di bidang keuangan menetapkan besaran tarif dan jangka waktu pengenaan Bea Masuk Tindakan Pengamanan sesuai dengan keputusan Menteri sebagaimana dimaksud pada ayat (4) paling lambat 30 (tiga puluh) hari kerja terhitung sejak tanggal diterimanya surat Menteri oleh menteri yang menyelenggarakan urusan pemerintahan di bidang keuangan". Sedangkan dalam hal penetapan kuota atau pembatasan jumlah barang oleh pemerintah yang dapat diimpor, kewenangan tersebut berada dibawah Kementerian perdagangan. Adapun jumlah kuota yang ditetapkan sebagaimana tidak boleh kurang dari jumlah impor rata-rata paling sedikit dalam 3 (tiga) tahun terakhir, kecuali terdapat alasan yang jelas bahwa kuota yang lebih rendah diperlukan untuk memulihkan kerugian serius atau mencegah ancaman kerugian serius terhadap industri dalam negeri.

\section{Kesimpulan}

Berdasakan pemaparan di atas, maka disimpulkan terdapat dua komponen yang memberikan gambaran jelas tentang perbedaan ketentuan safeguards yang terdapat di Indonesia dengan ketentuan yang terdapat di Amerika, yaitu: (1) Bentuk dan Isi perundang-undangan safeguards. Di Indonesia terkait dengan bentuk dan isi ketentuan tindakan pengamanan perdagangan ketentuan yang termuat dalam Undang-Undang Nomor 7 Tahun 2014 tentang Perdagangan masih bersifat sumir hanya terbatas pada legalisasi atau pandangan umum tentang beberapa kebijakan pengamanan perdagangan. Hal tersebut sangat bertolak belakang jika dibandingkan dengan ketentuan UndangUndang Perdagangan Amerika Tahun 1974 Nomor 421 yang lebih komprehensif dan jelas.

(2). Keterlibatan Kepala Negera dalam safeguards. Dalam Pasal 203 Undang-Undang Perdagangan Amerika Tahun 1974 Nomor 421 dijelaskan secara khusus mengenai sejauhmana peranan dan keterlibatan seorang kepala negara dalam upaya melindungi eksistensi industri nasional dari persaingan impor yang dapat berakibat pada lahirnya ancaman kerugian atau kerugian serius. Keterlibatan tersebut khususnya pada kewenangan wewenang melakukan seluruh tindakan yang dinilai cocok dan memungkinkan dilakukan melalui kekuasaannya. Tentunya hal tersebutberbeda dengan pelaksanaan tindakan pengamanan perdagangan yang terdapat di Indonesia, dimana dalam hal ini Kepala Negara tidak memiliki keterlibatan apapun, karena dari awal terkait pelaksananaan safeguards sejak awal telah diserahkan kepada tiga lembaga independen, yaitu Komite Pengamanan Perdagangan Indonesia (KPPI), Kemudian Dewan Pengamanan Perdagangan (DPP), serta yang terakhir adalah Kementerian Perdagangan dan Kementerian Keuangan.

Saran dari penelitian ini, yaitu perluanya ada suatu peraturan perundang-undangan yang secara komprehensif mengatur seluruh aturan tentang remedy perdagangan, baik itu yang berkaitan dengan Anti Dumping, Anti Subsidi ataupun Safeguards dalam satu satu perundang-undangan yang lebih tinggi, yang dalam hal ini adalah Undang-Undang sebagaimana yang telah dilakukan oleh pemerintah Amerika Serikat dalam UndangUndang Perdagangan tahun 1974. Selain itu perlu adanya kajian ulang dan pertimbangan kembali tentang keterlibatan lebih kepala negara dalam melakukan pengawasan dan pengambil keputusan dalam pelaksanaan tindakan pengamanan perdagangan di Indonesia.

30 Peraturan Pemerintah Republik Indonesia Nomor 34 Tahun 2011 tentang Tindakan Antidumping, Tindakan Imbalan dan Tindakan Pengamanan Perdagangan (Lembaran Negara Republik Indonesia Tahun 2011 Nomor 66, Tambahan Lembaran Negara Republik Indonesia Nomor 5225). 


\section{DAFTAR PUSTAKA}

\section{A. Buku}

Kartadjumena, 1986, Sistem Forum dan Lembaga Internasional, UI Press, Jakarta.

Lal Das, Bhagirath, 1998, An Introduction To The WTO Agreements, Trade And Development Issues and The Word Organisation, Third World Netwrok, Malaysia.

Mahmud Marzuki, Peter, 2014, Penelitian Hukum Edisi Revisi, Prenadamedia Group, Jakarta.

Sood, Muhammad, 2011, Hukum Perdagangan Internasional, Rajawali Press, Jakarta.

Weiler, J.H.H., Sungjoon Cho, dan Isabel Feichtner, 2011, International and Regional Trade Law: The Law of the World Trade Organization, Ebook

\section{B. Artikel Jurnal}

Kementerian Perdagangan Republik Indonesia, "Selamat Datang Undang-Undang Perdagangan”, Indonesia Trade Insight (INTRA), Edisi Perdana 2014

Ryan, David, "The Effects of Section 201 Safeguards on U.S. Industries," Georgetown Journal of International Law, Vol. 44.

Sutrisno, Nandang, "Memperkuat Sistem Hukum Remedi Perdagangan, Melindungi Industri dalam Negeri”, Jurnal Hukum Ius Quia Iustum, Vol. 2 No. 14, April 2007.

\section{Penelitian/Tesis}

Erika, 2009, Kebijakan Perdagangan Amerika Serikat: Kenaikan Tarif Impor Ban Cina Analisa Terhadap Motif Ekonomi Dan Politik Dari Kebijakan AS Dalam Menaikkan Tarif
Impor Ban Cina Pada Masa Pemerintahan Obama, Thesis, Fakultas Ilmu Sosial Dan Ilmu Politik Universitas Indonesia, Jakarta.

\section{Peraturan Perundang-Undangan}

Undang-Undang Nomor 7 Tahun 2014 tentang Perdagangan (Lembaran Negara Republik Indonesia Tahun 2014 Nomor 45, Tambahan

Lembaran Negara Republik Indonesia Nomor 5512).

Peraturan Pemerintah Republik Indonesia Nomor 34 Tahun 2011 tentang Tindakan Anti Dumping, Tindakan Imbalan dan Tindakan Pengamanan Perdagangan (Lembaran Negara Republik Indonesia Tahun 2011 Nomor 66, Tambahan Lembaran Negara Republik Indonesia Nomor 5225).

\section{E. Dokumen Resmi Lain}

General on Tariffs and Trade (GATT).

Undang-Undang Perdagangan Amerika Serikat tahun 1974 tentang Tindakan yang Mempermudah Penyesuaian Industri Terhadap Persaingan Impor.

Undang-Undang Perdagangan Amerika Serikat Tahun 1974 tentang Investigasi, Kebijakan dan Saran dari Komisi.

Undang-Undang Perdagangan Amerika Serikat tahun 1974 tentang Tindakan yang Diambil Presiden Setelah Penetapan Gangguan Barang Impor.

Undang-Undang Perdagangan Amerika Serikat tahun 1974 tentang Monitoring, Modifikasi, dan Pemberhentian Suatu Tindakan. 